\title{
DR FREDERICK MONTIZAMBERT (1843-1929): CANADA'S FIRST DIRECTOR GENERAL OF PUBLIC HEALTH
}

\author{
by
}

\section{GEOFFREY BILSON*}

Dr Frederick Montizambert served the Canadian government for over fifty years, rising from the position of assistant to the superintendent at Grosse Isle quarantine station to that of Canada's first Director General of Public Health. Although he was recognized internationally as a sanitarian and honoured by his fellow physicians at home and abroad, he never received the recognition that he felt he deserved from his employers, and he was denied the position which he craved at the end of his career, that of deputy minister in the new Department of Public Health established in 1919. Montizambert's frustrations arose partly from his own personality and partly from the limited interest in public health shown by the federal government of his day.

Born to a well-established Quebec family in 1843, Montizambert was educated in Quebec and at Upper Canada College. At the age of seventeen, he entered Laval University, where he studied medicine for two years. He then transferred to Edinburgh for three years, and returned to Quebec in 1864 as an MD and a member of the Royal College of Surgeons of Edinburgh. At Edinburgh, he took honours in nearly all his subjects, won prizes in a number, and served as dresser to James Syme and James Pettigrew and as assistant to T. Spencer Wells. On his return to Quebec, he was granted a provincial licence and began to practise. ${ }^{1}$

Montizambert was well placed to make a success of private practice. Young and vigorous, handsomely moustached and commandingly tall, well-educated and academically successful, he could call on his family's contacts to build his practice and rely on his private income to see him through the lean early years. He joined the militia and earned the Canada General Service medal for his services during the Fenian disturbances in $1866 .^{2}$ Over the next decade, he remained active in the military, which brought him into contact with influential members of Quebec society.

Despite his advantages of training and position, Montizambert never was very interested in private practice. He showed an early interest in public health questions

*Geoffrey Bilson, M.A., Ph.D., Professor of History, University of Saskatchewan, Saskatoon, Canada S7N OWO.

An earlier version of this paper was read at the CMA, Saskatoon, September 1982.

${ }^{1}$ H.J. Morgan, Canadian men and women of their time, Toronto, 1912. Public Archives of Canada (PAC) RG 17 I-1 vol. 15 file 1201-1240. 16 January 1865, Frederick Montizambert (FM) to Provincial Sec. mentions his licence although no record now exists in the archives of the Corporation Professionnelle des Médecins du Québec.

${ }^{2}$ CGSM Register 1866-70. PAC RG II A 5, vol. 3. 


\section{Dr Frederick Montizambert (1843-1929)}

and wrote to a Quebec newspaper in 1865 to warn of the need for precautions against cholera. ${ }^{3}$ There were, however, few openings for a young doctor who wished to make his career in public health rather than private practice. Municipal and provincial governments at this time treated questions of public health as emergencies. Whenever an epidemic threatened, boards of health were set up to deal with the immediate threat, only to be dissolved as the epidemic subsided. It would be some years before the need for permanent public health bodies was accepted. ${ }^{4}$ In 1865 , the only permanent institutions concerned with public health were the lazaretto at Tracadie, Nova Scotia, and the quarantine stations at the major ports of entry into British North America. Montizambert looked to Grosse Isle for his opportunity.

Grosse Isle lay thirty miles downstream from Quebec. A quarantine station had been opened on the island in 1832 to protect the Canadas from cholera and it had been in operation ever since. Each year, hundreds of ships carrying thousands of immigrants stopped at the island for inspection before proceeding to Quebec or Montreal. A small medical staff under the direction of the medical superintendent manned the station during the shipping season. The posts were few and eagerly sought, but Montizambert did succeed in getting an appointment as assistant medical superintendent, under Dr A. Von Iffland, in May 1866. The next year, he was reappointed but only after making repeated applications and only when the island was swamped with typhus cases. The appointment brought protests from the supporters of a rival candidate, and in 1868 Montizambert's petition for a post at Grosse Isle was set aside. ${ }^{5}$ The next year, however, saw the retirement of Dr Von Iffland and the death of Dr J.A. Lachaine, Montizambert's chief rival for the post. His petition for the post of medical superintendent at Grosse Isle was successful and he was appointed at a salary of $\$ 1000$ per annum. He was to hold the post for thirty years. ${ }^{6}$

Montizambert's success rested on his family's connexions, especially with John A. Macdonald, who was to be Prime Minister of the newly created Canada for many years after $1867 .{ }^{7}$ The young doctor had shown determination in his pursuit of the office, but his motives for seeking the position were never clearly spelled out. The appointment brought several disadvantages. It was not an annual one, but was valid only eight months of each year, during the navigation season. For the remaining four months, the superintendent had to fend for himself. Moreover, unlike his fellow quarantine officers at such ports as Halifax or St John, New Brunswick, the incumbent at Grosse Isle had little chance of building a private practice. Few residents of the city cared to choose as their family physician a man who was out of town for most of the year. The post also cut him off from many contacts with his fellow doctors. Montizambert joined the Canadian Medical Association (CMA) on its foundation in 1867 , but his duties prevented him from attending a meeting before

${ }^{3} 23$ October 1865, clipping in PAC MG24 D16, vol. 48, p. 38745.

4 Heather A. MacDougall, 'The genesis of public health reform in Toronto, 1869-1890', Urban History Review, 1982, 10(3): 1-9.

' 1 February 1868, petition, PAC RG 17 A 1, vol. 18, no. 1550.

${ }^{6} 8$ March 1869, petition to Gov. General, PAC RG 17 A 1, vol. 27, no. 2837; 18 March 1869 appointed $^{\circ}$ on death of Dr Lachaine, PAC RG 32, C2, vol. 683.

727 May 1867, J.A. Macdonald to E. Montizambert, PAC MG26A, vol. 513, microfilm C-25. 


\section{G. Bilson}

1899. Montizambert chose a life he enjoyed, with its seasonal rhythm of life with his family on the island in the summer and winters spent travelling and studying, but he paid the price of some professional isolation. Over the years, he tended to grow opinionated and somewhat self-satisfied.

Montizambert went to work for the federal government and remained a federal civil servant until his retirement. At the time he made his decision, no other level of government offered a career in public health, but by remaining in the federal service he sharply limited the range of his activities over the next few years. The British North America Act of 1867, which had created Canada out of a number of provinces, had laid down a division of powers between the federal and provincial governments, some of which affected public health and related questions. Section 91 (11) provided that quarantine and the provision of marine hospitals would be the responsibility of the federal government, while Section 92 (7) left the provision of hospitals (other than marine hospitals), asylums, and eleemosynary institutions in the hands of the provinces. The effect of this separation was to leave the jurisdiction over public health largely in provincial hands. Section 95 gave concurrent powers over agriculture and immigration to the federal and provincial governments. A series of negotiations between the different governments divided the responsibility for immigrants. The federal government appropriated the power to admit immigrants and agreed to meet the costs of quarantine and inspection of those entering the country. The provinces undertook to encourage immigration. Replying to criticisms, in 1892, that immigrants were a threat to the public health, the Minister of Agriculture said that public health and quarantine were distinct matters and that the federal government had no role in public health. In practice, however, the distinction was not that clear-cut. The federal government could play a part in major epidemics, for example, but it was generally content to leave nuhlic health matters in municipal and provincial hands. ${ }^{8}$

The quarantine would be Montizambert's central professional concern for thirty years. As soon as he took up his duties at Grosse Isle, Montizambert began to offer suggestions for improving the facilities on the island and for making the quarantine more efficient. The system in use was essentially that devised in the 1830 s to deal with the threat of cholera. Created in the days when most passengers arrived in crowded sailing vessels, the regulations required that the larger ships stop at Grosse Isle for inspection. There, dirty vessels could be cleaned and their passengers required to wash themselves and their baggage. Vessels with sickness on board could be detained for the incubation period of the disease. The system was cumbersome, delays to some vessels were long, and the results never entirely satisfactory. ${ }^{9}$ Both Canadians and Americans complained that the St Lawrence route brought disease into the continent. ${ }^{10}$

As superintendent at Grosse Isle, Montizambert's chief concern was to make the quarantine effective. He devoted much of his energy to studying developments in

\footnotetext{
8 August 1892, PAC MG29E 18 vol. 11 file 10; W.H. McConnell, Commentary on the British North America Act, Toronto, Macmillan, 1977, pp. 201, 257, 304-305.

918 April 1872, FM to Minister of Agriculture (MAg), PAC RG 17 A 1, vol. 61, no. 5843; 17 June 1872, FM to MAg, PAC RG 17 A 1, vol. 65, no 6278.

${ }^{10}$ Ann. Rep. Min. Ag. 1881, Ottawa 1882.
} 
practice reported at international sanitary conferences. Each winter, while the station was closed and his duties suspended, Montizambert travelled to medical conferences in the United States. His annual reports to the Minister of Agriculture grew lengthier as he incorporated what he had learned into suggestions for rearranging and improving the facilities at Grosse Isle.

Improved facilities at the station, however, were of little use if ships did not stop. In Montizambert's first years on the island, conditions of transatlantic travel quickly changed. Most passengers chose steam over sailing vessels, for the added expense was outweighed by the increased speed and better quarters the steamers offered. For the shipowners, speed was profit and delays of quarantine were costly. Rather than risk losing time, vessels passed the island at night when the station was closed, or simply ignored the regulations. In 1882, Montizambert reported that no vessel had stopped at Grosse Isle for inspection. ${ }^{11}$ After fifty years in operation on the St Lawrence, quarantine appeared to be on the way to becoming obsolete.

While Montizambert struggled in these early years of his career to salvage something at Grosse Isle, interest in public health was growing elsewhere in Canada. As early as 1863 , the fear of smallpox had led the parliament of the Canadas to provide for compulsory vaccination of infants. After Confederation, Ontario required municipalities to make vaccination available to the poor without charge. Montizambert was an advocate of compulsory vaccination and, in 1871, asked for a change in regulations to allow him to compel passengers and sailors to be vaccinated. He complained that without the change he could not demand vaccination "without exposing myself to one of these vexatious prosecutions with which it is too much the fashion to harass medical men who are considered to have exceeded their authority."12 The government, however, preferred not to insist on vaccination.

The threat of smallpox in Ontario produced major public health legislation. In 1873, a Public Health Act had left the responsibility for those matters in the hands of the municipalities. Little was done before 1882. In that year, the Ontario government appointed a provincial board of health to prepare against the expected outbreak of smallpox. By 1886, the board had established its authority and was overseeing vigorous and co-ordinated municipal public health activity. Similar developments occurred in Quebec. In 1876, Montreal had established a health bureau charged with improving the sanitary condition of the city. The smallpox epidemic of 1885, which killed three thousand people in Montreal, helped to build support for the Quebec Public Health Act of 1886, which established a provincial health board and required municipalities to establish health boards. ${ }^{13}$

The health boards hired doctors. In the 1870s, McGill University in Montreal offered its first courses in public health, and Laval University faculty also developed

\footnotetext{
${ }^{11}$ Ann. Rep. Min. Ag. 1882 Ottawa, 1883, App. 21, p. 223. Geoffrey Bilson, 'Science, technology and 100 years of Canadian quarantine', in R.A. Jarrell and A.E. Roos (editors), Critical issues in the history of Canadian science, technology and medicine, Thornhill, Ont., HSTC Publications, 1983.

126 May 1871, FM to MAg, PAC RG 17 A 1, vol. 46, no. 4396; Paul Adolphus Bator, 'The health reformers versus the common Canadian: the controversy over compulsory vaccination against smallpox in Toronto and Ontario 1902-1920', Ontario History, 1983, 75(4): 349-350.

${ }^{13}$ Barbara Lazenby Craig, 'State medicine in transition: battling smallpox in Ontario 1882-1885', ibid., 320-321; Terry Copp, 'Public health in Montreal 1870-1930', in S.E.D. Shortt (editor), Medicine in Canadian society, Montreal, McGill-Queens University Press, 1981, p. 396.
} 


\section{G. Bilson}

an interest in these questions. Careers in public health began to open up and medical health officers formed the Association of Executive Health Officers of Ontario (AEHOO) in 1886, which was modelled on British and American examples. Many Canadians became active in the American Public Health Association, which had been founded in 1872 . The new breed of health officer - and by 1889 there were 300 of them in Ontario-was vocal and visible in lobbying for public health measures to be taken by municipal and provincial governments. Dr Peter $\mathrm{H}$. Bryce, the first secretary of the Ontario Board of Health and secretary treasurer of the AEHOO, became a well-known public figure through his lectures and writing. Dr Edward Playter founded the Sanitary Journal in 1874 and became one of the best-known agitators for public health measures over the next decade. ${ }^{14}$ Both men would have dealings with Montizambert.

The new public health specialists were interested in immigration. Their careers opened up in the years of increased immigration, which made the St Lawrence a busy route into Canada and the USA. An efficient quarantine was seen as a first line of protection against disease and the doctors demanded improvements in the quarantine. In the last years of the century, many of the doctors would call for more careful selection of immigrants before they left Europe, arguing that the immigrant represented a long-term threat to the health of Canadians greater than that posed by infectious disease. The demand for restrictions on immigrants led to changes in the Immigration Act in 1902, which banned whole categories of would-be immigrants including the epileptic and the "feeble minded". ${ }^{15}$

Montizambert welcomed the surge of interest in public health. Like his new colleagues, he looked to science as the key to protecting the public, and it was science which would save the quarantine from obsolescence by making it efficient. In his annual report of 1885 , Montizambert announced that "the germ theory is a fact". From that fact there followed important consequences. Influenced by Dr Rouch of Chicago, who visited Grosse Isle in 1885, and by the work of Dr Joseph Holt of New Orleans, Montizambert announced that maritime sanitation should replace quarantine detention. ${ }^{16}$ Ships did not need to wait through the incubation period of a disease. Passengers could be removed while the vessels were cleaned and disinfected by steam or chemicals. The passengers' belongings could be scientifically sterilized, not washed in the waters of the St Lawrence. Montizambert's message came at an opportune time. In 1885, the large-scale smallpox epidemics led the federal government to listen to Montizambert and to act on his advice. After 1886, quarantine regulations required all passengers and crews to show signs of vaccination or submit to vaccination on arrival in Canada. A steam yacht, the Hygeia, replaced the rowboats at Grosse Isle. The yacht was able to pump steam into the holds of ships to "displace the dangerous atmosphere and replace it with one

\footnotetext{
${ }^{14}$ Heather Macdougall, 'Enlightening the public: the views and values of the Association of Executive Health Officers of Ontario 1886-1903', in Charles G. Roland (editor), Health, disease and medicine: essays in Canadian history, Toronto, Charles Irwin (for the Hannah Institute), 1984.

${ }^{15}$ Geoffrey Bilson, “Muscles and health:" health and the Canadian immigrant 1867-1906" in ibid.

${ }^{16}$ F. Montizambert, 'The story of fifty-four years' quarantine service from 1866-1902', J. Canad. med. Ass., 1926, 315; Ann. Rep. Min. Ag. 1885, Ottawa 1886, pp. 151-154.
} 
intensely germicidal". Delegates to the American Public Health Association, meeting in Toronto, applauded the new procedures. ${ }^{17}$

This was just the beginning for Montizambert. He continued to press the goverment for major changes which would bring a system of marine sanitation into effect. Once again, the threat of epidemic disease encouraged the government to accept his advice. For the first time since the regulations had been written to deal with the danger of cholera in the $1830 \mathrm{~s}$, extensive changes were made in the quarantine regulations in anticipation of cholera in 1887. All ships had to stop at Grosse Isle, where the station would be open twenty-four hours a day. Ships had to provide hospitals and isolate passengers with infectious diseases. Vessels carrying diseased passengers were disinfected. All passengers with infectious disease, major or minor, were detained at Grosse Isle and their contacts were disinfected. Despite his support for the idea of compulsory vaccination, Montizambert agreed to drop the requirement in the case of cabin passengers. In a concession to contemporary sensibility, he expressed his sympathy for "ladies [who] find themselves suddenly and unexpectedly confronted with the requirement that they must show their arms to, and possibly submit to vaccination by, a ship's surgeon, or a quarantine officer, about whom they know nothing and in whom and the purity of whose vaccine, they may have no confidence." Even with this concession, he said, the new regulations marked "an entirely new era in the history of the quarantine system in the St. Lawrence."18

The new system of the St Lawrence was widely praised. Montizambert was made a DCL at Bishop's University for his "service to the Dominion as Health Officer, for your able reports, and your scientific standing which has been recognized beyond the limits of our Dominion."19 On a tour of Europe in the winter of 1888-89, he found that in London the people in charge of the disinfecting facilities "all seemed very familiar with my name etc.". He was invited to Edinburgh to be made a fellow of the College of Surgeons. In Paris, he was received by Louis Pasteur. "He showed me all his laboratory work and I followed the inoculations of a number of patients he had under treatment at the time. Most interesting." ${ }^{20}$ On his return from Europe, he was put in charge of the whole St Lawrence quarantine, and took on a heavier work-load as he attempted to ensure that his new system was effectively applied. The tempo of his off-season work increased as he accepted invitations to chair sessions and sections at international conferences in Washington and London. ${ }^{21}$ In 1890, Montizambert was elected President of the American Public Health Association. In the next few years, he would be elected to honorary membership of public health organizations in Britain, France, and Mexico. ${ }^{22}$

The five years in which he was in charge of the St Lawrence quarantine were difficult ones for Montizambert. He became increasingly dissatisfied by the treatment which he received from his employers. They continued to pay him for the

${ }^{17}$ Ann. Rep. Min. Ag. 1886, Ottawa, 1887, pp. 159-165.

${ }^{18}$ Ann. Rep. Min. Ag. 1887, Ottowa, 1888, pp. 180-183.

1923 June 1888, FM to John Lowe (JL), PAC RG 17 A 1.9, vol. 1679.

2020 March 1889, FM to JL, PAC RG 17 A 1.9, vol. 1679.

${ }^{21}$ PAC MG29, C101, vol. 1.

22 Ibid. 


\section{G. Bilson}

eight months of the year when the St Lawrence was open but called on him for advice on public health questions throughout the year. Neither were they slow to trade on his reputation to defend the government from criticism on public health questions. When, for example, the Medico-Chirurgical Society of Montreal resolved, in 1892, that the quarantine was inefficient, the Minister of Agriculture replied that the government was advised in these matters by "a man who had given up his whole time for many years to a particular study of this subject". ${ }^{23}$ In that same year, Dr Bryce and Dr Playter suggested that recent cases of smallpox among immigrants in Winnipeg and Ontario had slipped by the quarantine. Playter published a report on conditions at Grosse Isle, and Montizambert was instructed by his superiors to publish a reply. The Deputy Minister told Playter that the question was one "as to whether Dr. Montizambert or Dr. Playter should command the larger sphere of public confidence." In a lengthy article in the Ottawa Daily Citizen, Montizambert dismissed the charges as "trivial, silly, untrue and easily refuted", described Playter as "the laughing stock of the hospital staff [at Grosse Isle] who speak of him with the utmost contempt", and emphasized his own qualifications and reputation. ${ }^{24}$ There was no reply from Playter.

Montizambert responded to the increased use of his time by pressing the government for an adequate salary. He had private means, and both his wife and her unmarried sister, who made her home with them, had inherited property which Montizambert managed for them. Each woman was reported to have left him over $\$ 250,000$ at her death. ${ }^{25}$ Montizambert had a growing family, but it seems likely that his battle for an adequate salary was more a matter of professional pride than of necessity. It was certainly a long-standing issue, for Montizambert had never felt that he was being fairly paid for his work since his appointment in 1869. At that time, he had been paid $\$ 1000$ a year, which was little more than half his predecessor's salary. The explanation for the cut was that it was a temporary measure because $\mathrm{Dr}$ Von Iffland had been paid a retiring allowance. When the balance was not restored in 1870 , Montizambert protested, but it was only in 1873 that his salary was raised to $\$ 1200 .^{26}$

For the next decade and more, Montizambert argued for an increase to $\$ 3200$, which he settled on as an appropriate reward for his services. The Deputy Minister of Agriculture responded in 1884 that there was always "a great gulf between what you as a professional man thought was a befitting salary for your attainments and experience and the opinions of the Ministers in relation to the same." ${ }^{27}$ Nevertheless, Montizambert tried a variety of arguments. He believed that that his strongest reason for a good salary was his skill and experience. At first, he pressed for a salary suitable "for a university man at the head of so important a station". ${ }^{28}$ Later, he argued that his branch of medicine "constitute[d] a speciality" with skills "not to be found in any

\footnotetext{
${ }^{23}$ PAC MG29 E18, vol. 11, file 10.

246 June 1893, JL to FM, PAC MG29 E18, vol. 5, 75-77; 16 June 1893, Ottawa Daily Citizen.

${ }^{25}$ PAC MG29 C101, vol. 2, file W. Walker estate 1869-1884. Ibid., vol. 1.

${ }^{26} 2$ April 1872, FM to J.H. Pope, PAC RG 17A1, vol. 615804; 15 August 1873, PAC RG32 C2, vol.

${ }^{27} 15$ February 1884, JL to FM PAC RG 32 C2, vol. 683.

${ }^{28}$ FM to J.A. Macdonald, PAC MG 26A, vol. 432, pp. 212656-759, micro C-1780.
} 683. 
and every general practitioner without special study or experience." The operation of the quarantine required the application of "advanced processes of rapid chemical and steam disinfection which now makes maritime sanitation a speciality."29 As public health careers developed in the 1880 s, Montizambert pointed to the growing number of city health officers who were paid from $\$ 2400-\$ 4000$ a year "for a few hours work a day" which left them free for private practice. He complained that even vets in the federal service were paid more than he, while the director of the governmental farm was paid $\$ 4000$ and given a house. ${ }^{30}$ Montizambert was not above using a pathetic approach, "with my seven children now growing up, schooling more expensive ... I am anxious to know whether I am to obtain suitable income from government or if I am to be inadvertently obliged to obtain it elsewhere.",31

Montizambert was "surprised and hurt" in 1887 when his salary was raised only to $\$ 2400 .^{32} \mathrm{He}$ continued to argue for a further increase, even winning a couple of interviews with the Prime Minister to press his case. Montizambert now asked for a yearly salary at the monthly rate paid him at Grosse Isle, which would bring him $\$ 3600$ a year and recognize the consulting work he did in the winter. ${ }^{33}$ In 1890 , after he was put in charge of the St Lawrence quarantine, the Privy Council did agree to pay him $\$ 3000$ for eight months. The government found itself in trouble in the House of Commons. Delays in administration led to an appropriation of $\$ 4659$ for Montizambert in the supply bill introduced in 1891. Opposition MPs demanded an explanation, and the Minister had to explain that the sum represented salary, arrears, allowances, and payments for extra services over a number of years. One member wanted to know why Montizambert was paid horse hire and livery on Grosse Isle. "He gets a living allowance of $\$ 129.50$. He will be charging us for his boots and socks next." Another MP objected that "this man is a very expensive officer". ${ }^{34}$ It was not a reception in the house likely to make the Privy Council sympathetic to Montizambert's demands.

Outside pressure on the government did strengthen Montizambert's position slightly in the early 1890s. The Canadian Medical Association in 1892 called for the appointment of a permanent executive officer to supervise all matters of public health and quarantine and vital statistics and a permanent officer "of the highest scientific attainments, a well known sanitarian and one devoted to the work" to supervise all the quarantine stations in the Dominion. ${ }^{35}$ The Deputy Minister advised the Minister of Agriculture that this suggestion could be met by employing Montizambert all year around. ${ }^{36}$ Montizambert now tried to force the government's hand. Encouraged by his feeling that the Department needed him, he went on strike. "Unless I be given the office and salary the prospect of which has been for years held

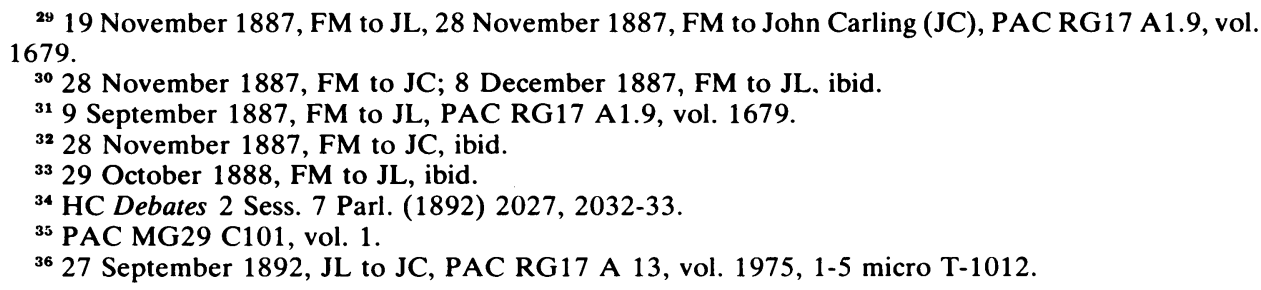




\section{G. Bilson}

before me as an inducement to give my gratuitous services", he wrote, he would refuse to be consulted on health matters in the winter months. ${ }^{37}$ The Department responded by suggesting that Montizambert be recognized as official adviser by Order in Council and be paid a fee for services given in the winter. Montizambert rejected that suggestion for professional reasons. He did not wish to be accused of offering advice in order to earn the fee. He did not wish to be dependent on laymen realizing that there was a medical problem before they asked for advice. He did not wish to spend "days, weeks, months" on a study of a health question, such as the movement of disease around the world, and then find himself paid nothing if he had no changes in policy to recommend. A fee for service payment would produce a situation "intolerable for any active man with any self respect". ${ }^{38}$

Montizambert rested his hopes on the demands being made for the appointment of a superintendent of quarantines and medical adviser to the Dominion government. He was convinced that he was uniquely qualified for the post. As he told his Minister, "I am the only person in Canada who has devoted himself for a lifetime (27 years) to this special branch. The only person who combines a lifetime of special study with a lifetime of practical experience in quarantine and maritime sanitation... and if Canada wants my services.... I consider them well worth the addition of four months pay." ${ }^{39}$ The Prime Minister, however, was not persuaded. On the contary, he thought "that this situation should not continue", and considered demoting Montizambert to his former post as Superintendent of Grosse Isle. ${ }^{40}$

Unaware of the Prime Minister's feelings, Montizambert saved himself from this fate by returning to work early in 1893 . Professional interest broke his strike when he responded to a request for a plan to cope with the threat of cholera in 1893. Toward the end of the year, however, Montizambert renewed his campaign for a year-round appointment as superintendent of Canadian quarantines. The USA was considering creating such a post in that country, on the recommendation of the American Public Health Association (APHA) The Minister of Agriculture now advised the Privy Council that the appointment should be made and early in 1894, Montizambert was appointed superintendent of Canadian quarantines at a salary increase of $\$ 1000$ per annum and year-round employment. Montizambert's response was to write to his Minister, A.R. Angers, regretting that the appointment had not been made retroactive to the autumn of 1893. This complaint offended Angers, who was further annoyed when Montizambert complained later in the year that he had been "fine[d] $\$ 244$. a year" by the abolition of the daily ration allowance paid during his time on Grosse Isle. He seemed unable to gain satisfaction from his respectable annual salary of $\$ 4000$, which was four-fifths the salary of a deputy minister. ${ }^{41}$

Montizambert was now responsible for quarantine stations on the St Lawrence and at Halifax, N.S., St. John, N.B., and William Head, B.C. The stations were

${ }^{37} 28$ December 1892, FM to JL, PAC RG32 C2, vol. 683.

${ }^{38} 28$ December 1892, FM to A.R. Angers, ibid.

${ }^{39} 10$ January 1893, FM to A.R. Angers, ibid.

${ }^{40} 15$ July 1895 , JL to FM, PAC RG17 A1.5, vol. 1631 micro T-131. This correspondence reviewed Montizambert's career to this date.

417 December 1893, 8 February 1894, 15 February 1894 , JL to FM; 27 July 1896, FM to Scarth, PAC RG32 C2, vol. 683. 


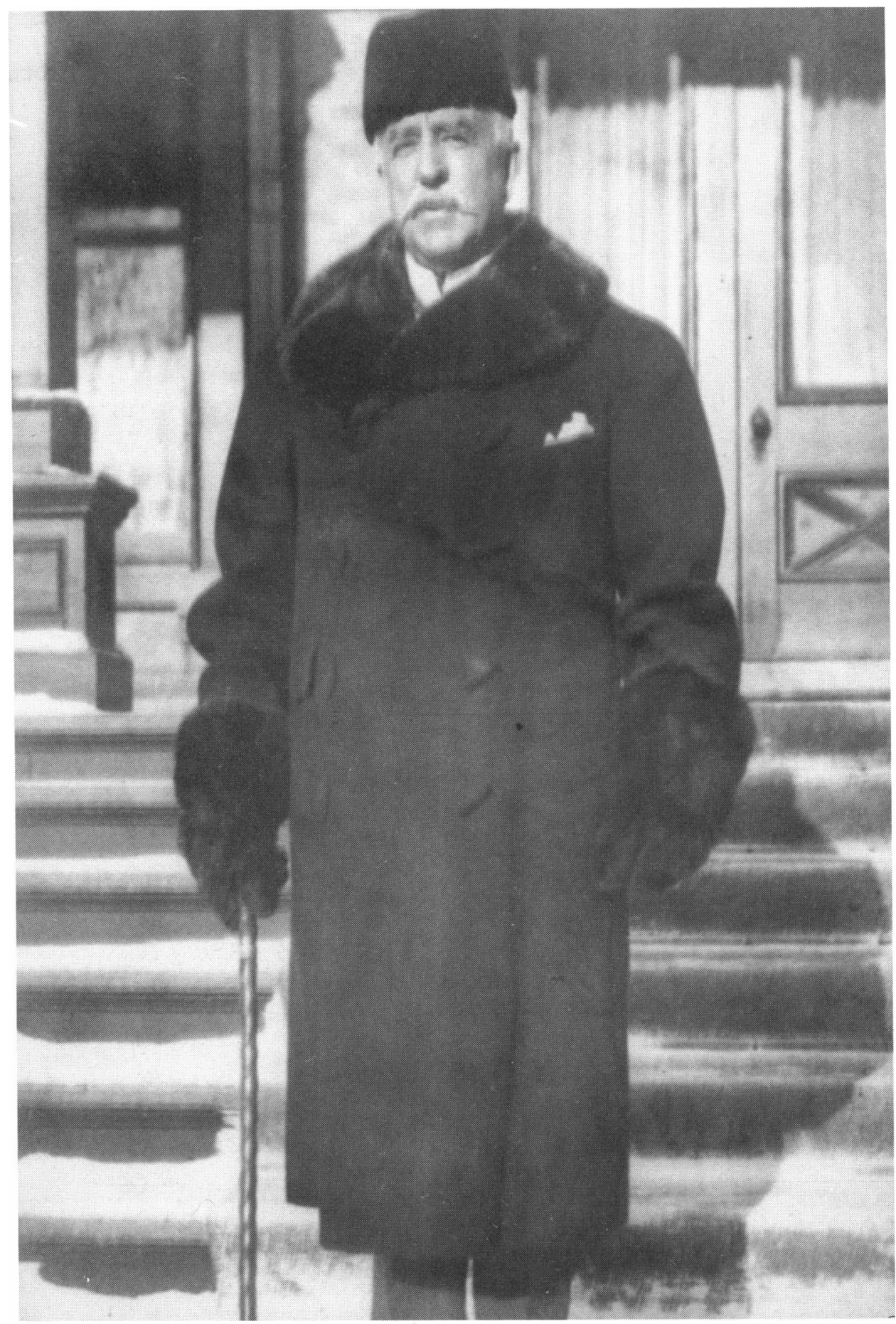

Plate 1. Dr Frederick Montizambert, ISO, CMG. (Photo: Public Archives of Canada) 


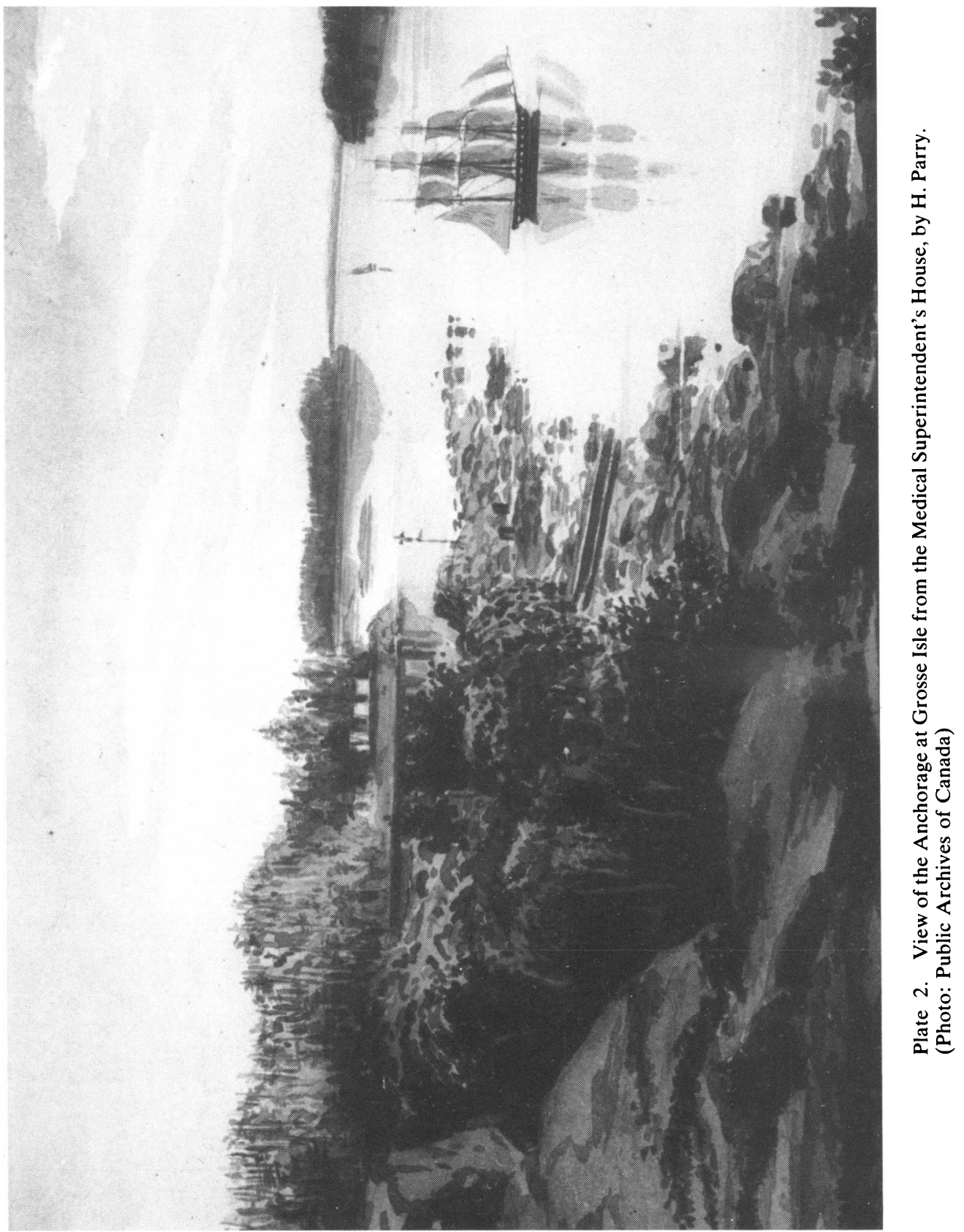


operated under regulations that Montizambert had drawn up in 1893, based on his own experience and recommendations of the Sanitary Conference held in Vienna in 1892. The stations were equipped with machinery to provide for the steam disinfecting of all imigrants' baggage, and requirements for inspection of immigrants, especially at the US border, were tightened. In his new post as superintendent, Montizambert continued to keep Canadian quarantine in touch with developing techniques of disinfection and he adopted the policy of notifying provincial boards of health when infectious diseases were reported at the stations. He was eager to see that his regulations were being carried out. This led him quickly into fresh conflict with his superiors. On his appointment, he had suggested that he should be free to visit quarantine stations when he felt it necessary. The Minister had turned down that suggestion, but Montizambert acted on it in 1894 by visiting officers appointed to deal with the threat of smallpox. He was reprimanded for his insubordination.

It soon became clear that what was at issue was the question of political constraints on professional actions. Montizambert wished to be largely free of restraints when he chose to act in a professional way, and he was jealous of his professional rights. Thus he objected when the Deputy Minister of Agriculture sent out a circular letter of instruction to smallpox inspectors, on the grounds that it was a "purely professional duty". When Montizambert included a reference to the superintendent of the quarantines in the regulations, the Minister of Agriculture struck it out of the proofs because the reference "might be held to imply a limitation of the Minister's plenary authority". It was a conflict that Montizambert had little hope of winning. The superintendent was to act on instructions from his Minister, even if they did limit his freedom to act as he chose. Montizambert was reminded that he must expect "lay criticism" and sometimes to find his "professional views not carried out".42

Montizambert was little known outside professional circles, unlike some of his provincial colleagues, such as P.H. Bryce, who was becoming a public figure in these years. The middle $1890 \mathrm{~s}$, however, brought him continued recognition as one of Canada's more important public health officers and Montizambert took pleasure in the status granted him by such bodies as the APHA. In 1896, that organization appointed him to a committee "to formulate international sanitary regulations governing the migration of European populations to America." His duties at Grosse Isle each summer limited his freedom, but he did show a broadening interest in public health questions by accepting an invitation to join the council organizing the Canadian Branch of the National Society for Aid to Sick and Wounded in War. He began to work with the Canadian Tuberculosis Committee in $1901 .^{43}$

As Canada grew in the later nineteenth century, some advocates argued the need for a larger role for the federal government in public health matters. Over a million immigrants entered Canada in the last twenty years of the century, and the provinces began to consider sharing the cost of dealing with those who were sick or indigent. The division of powers seemed to some to be less suited to the needs of the developing country than it had been in the 1860 s. The medical officers of Ontario,

${ }^{42} 8$ July 1895, JL to A.R. Angers, PAC MG29 E18, vol. 5, 571-81; 15 July 1895, JL to FM, PAC RG17 A1.5, vol. 1631, micro T-131.

${ }^{43}$ Ann. Rep. Min. Ag. 1896, Ottawa, 1897, p. 14, 17; 1 October 1896, G. Sterling Ryerson to FM, PAC MG29 C101, vol. 1; PAC MG28 175, vol. 1(b), file 2, 5, micro C-4480. 


\section{G. Bilson}

for example, argued that modern medicine required accurate statistics and that the federal government should assume responsibility for their collection, The problems of disease control in a mobile society required an authority that was not limited by provincial boundaries. The developing nation, they argued, needed a federal public health authority. ${ }^{44}$ The federal government responded slowly to these suggestions, but it did decide to co-ordinate its existing public health functions by appointing a Director General of Public Health.

In January 1899, Montizambert was appointed as Canada's first Director General of Public Health. In part, the appointment was given to him "in special recognition of his long service and special attainments as a Sanitary Expert." In part, also, it was for the convenience of his superiors. Since his appointment as a year-round employee, the department had tried unsuccessfully to persuade him to spend his winters in Ottawa. Montizambert preferred to winter in Toronto. Now, relieved of his duties at Grosse Isle for the first time in thirty years, Montizambert could be required to spend all his time in Ottawa. His new duties were to serve as "Sanitary Advisor to the Dominion Government, as General Superintendent of Quarantines... and inspector of the Tracadie Lazaretto."45

The new post brought him the rank of Deputy Minister but no increase in salary. The promotion was technically illegal because he was not given a vacant position or put in charge of a new department created by Act of Parliament. In 1905, this illegality was resolved by an Act of Parliament that confirmed him as a Deputy Minister. Motizambert chose to interpret this as a special act of favour, rather than a piece of housekeeping, and always referred to the fact that he was a Deputy Minister "by Act of Parliament". ${ }^{46}$ The fact that he had no department to administer limited the part he could play in asserting leadership in public health matters even within the branches of the federal government. In the early years of the twentieth century, the Department of Marine and Fisheries created a small office which dealt with sick sailors. In the Interior Department, to which Montizambert was attached, a separate medical service was established to meet the requirements of the Immigration Act. Dr Bryce joined the federal service in 1902 to oversee the immigration medical service, and Montizambert had no control over it. ${ }^{47}$

Montizambert had no chance to build an empire out of his position. He devoted his apparently unflagging energy to the functions given to him as Director General. In his role as inspector of the Tracadie Lazaretto, he found a new interest. The lazaretto in New Brunswick and, after 1906, that in British Columbia, housed small groups of lepers who aroused Montizambert's sympathy. He took his usual approach to the question and ransacked the literature for the latest information. In additon, he corresponded with authorities on the treatment of leprosy. He concluded that the most promising treatment of the disease appeared to be chaulmoogra oil. The oil had

44 MacDougall, op. cit., note 14 above, p. 446.

4514 January 1899, Report to PC, PAC MG 28175 vol. 1(b), file 2.5, micro C-4480.

417 November 1899, Richard Cartwright to W. Laurier, PAC Laurier Papers Series A Correspondence vol. 130, 39028 micro C-770; 12 July 1905, HC Debates 1 Sess. 10 Parl. 9688-90 Royal assent 20 July 1905 ibid. 9822 . For Montizambert's interpretation see op. cit., note 16 above.

17 J.P.D. McGinnis, 'From health to welfare', Ph D thesis, University of Alberta 1980, discusses the years before the establishment of the Department of Public Health in 1919. 
been used without success at Tracadie some years before, but it was now reintroduced and the treatment modified untilMontizambert was able to claim some success. Montizambert wrote on one occasion: "It is, however, a pleasant coincidence, if it is nothing more, that five of these unfortunate creatures should have been relieved of all the active symptoms of this loathsome disease and restored to perfect health during the few years of the treatment which I have instituted for leprosy cases throughout the Dominion." That tone of self-congratulation was probably present in the interview which Montizambert gave to a reporter. The resulting news story brought Montizambert mail from correspondents around the world who had read of his "cure" for leprosy. ${ }^{48}$

As sanitary adviser, Montizambert collected information about the movement of disease around the world and published his findings in his annual reports. These finally became so extensive that the government passed an order-in-council in October 1917 requiring that reports be confined to short statements of departments' work and exclude "contributions to knowledge in the form of scientific discussion". Montizambert, though hurt, obeyed. ${ }^{49}$

The major part of his work continued to be the quarantine. He travelled to each quarantine station annually and dealt with a steady stream of correspondence around the year. Since his proclamation about the germ theory years before, Montizambert had developed his interest in bacteriology. As superintendent, he insisted that quarantine doctors "go through a qualifying course of bacteriology" before taking up their posts. He arranged for each station to have a laboratory. The laboratories were used at time of epidemic disease to check potential carriers. In 1917, for example, all passengers arriving from India and China where cholera was prevalent were examined at William Head quarantine station. ${ }^{50}$ Montizambert ran the quarantine conservatively, requiring quarantine for the minor infectious diseases as well as major, discounting the effectiveness of substituting surveillance for quarantine in Canada, and recommending against Canada's joining an international sanitary convention that discontinued the practice of fumigating mail. The government responded to many of his requests to provide baths, showers, and steam disinfectors to ensure that immigrants entered Canada as free from disease as the quarantine service could make them. The problem of selecting healthy immigrants and rejecting the unfit, however, fell to the Immigration branch of the Department of the Interior, whose medical officer, Dr P.H. Bryce, was regarded by Montizambert more as a rival than a colleague.

Free at last to spend his summers on the mainland, Montizambert became an active participator at the meetings of the CMA, timing his annual inspection trips to quarantine stations so that he could attend meetings wherever they were held. Through his membership in the CMA, he was able to lobby discreetly for a project

\footnotetext{
414 March 1900, FM to Dr L.Duncan Bulkley, PAC RG29, vol. 5, 126293; Montizambert, op. cit. note 16 above, p. 317; 2 November 1912, FM to MAg, PAC RG29, vol. 4, 225273; 19 November 1907 , FM to G.K. Narayan, PAC RG29, vol. 4, 191525-6; 2 January 1913, FM to Dr B. Barker (Trinidad), PAC RG29, vol. 5, 233287.

${ }^{4}$ Ann. Rep. Min. Ag. 1918, Ottawa, 1919.

${ }^{50} 20$ January 1902, FM to P.H. Bryce, PAC RG29, vol. 19, file 10-3-1, pt. 1, Ann. Rep. Min. Ag. 1900, Ottawa, 1901, p. 12; Montizambert op. cit., note 16 above, p. 318.
} 


\section{G. Bilson}

increasingly dear to him and to the CMA - the establishment of a department of public health. However frank he might be in private correspondence with his superiors, Montizambert felt that he had to be discreet in public. "As an officer of the present Government it would not be proper for me to take any part ... beyond bringing to my Minister's attention what is the evident feeling of the medical profession." His position led him to decline to serve on a committee of the APHA established to formulate ideas on the work, powers, and duties of a national health department in USA, Canada, Mexico, and Cuba. ${ }^{51}$

Montizambert did plead publicly for the establishment of a department when he made his presidential address to the CMA in 1908. This paper, on 'Hygiene and sanitation - domestic, municipal, national, and international' was a historical sketch of the development of public health, laced with personal and slightly idiosyncratic judgements. "The new woman now-a-days is forcing herself forward as a competitor with men in almost every line of life. Nature tells us in several ways that this should not be so." Women lacked moustaches, which were designed "to act as a dust filter and protection for the nostrils (and it should therefore be all brushed upwards)" and it "must surely be nature's indication that she is intended for the shelter and protection of the home." There, she could contribute to public health by wielding her broom vigorously, for nature had provided her with eyebrows to catch the sweat. Moving away from an analysis of the role of women, Montizambert argued the need for a nationally co-ordinated effort to defend the public health. The Dominion government could play its part by fighting tuberculosis, overseeing railroad sanitation, and supporting bacteriological laboratories. The future would bring increased international co-operation and an Age of Universal Sanitation when men would turn their energies from war to secure the public health. ${ }^{52}$

Pressure from the CMA, trade unions, and the National Council of Women for a federal department of public health mounted steadily in the years before the First World War. Montizambert, however, was never to have a department of his own. Not until the war was nearly over and the country faced the prospect of welcoming home thousands of soldiers suffering from venereal disease did the government act. Montizambert was present at the Dominion and provincial conference of governments and social agencies in the spring of 1919, which unanimously endorsed the need for a department and gave it a fuller role to play than Montizambert had sketched eleven years earlier. N.W. Rowell, introducing the bill to create the department, said that it would be concerned with "all matters and questions relating to the promotion of health and social welfare of the people of Canada over which the Parliament of Canada has jurisdiction." ${ }^{33}$

It was now fifty years since Montizambert had joined the federal service. He had rank and decorations, but he longed to close his career as the first deputy minister of the new department. No one, he felt, could do the job better. He recommended that

5124 November 1903, FM to Dr George Elliot, PAC RG29, vol. 19, file 10-J-1 pt. 1; 1 March 1907, FM to C.O. Probst, ibid.

526 September 1908, FM Presidential Address, Montreal Med. J. 1908, 37(7): 477-492.

5329 May 1919, PAC MG26 H1(1), vol. 228, 128128; 26 March 1919, 4 April 1919, HC Debates, 2 Sess. 13 Parl. (1919) 843, 1165. 


\section{Dr Frederick Montizambert (1843-1929)}

the government set up an advisory council for the department. "I may say without egotism that $I$ have not felt very urgently the necessity for such an advisory council, but I am one of the very few men, if not indeed the only one, in Canada who has devoted his whole life service to sanitation and public health .... I do feel, however, that the term of my natural and official life cannot be much further prolonged." His less experienced successor, however, would benefit from the help of a board. Writing to the Prime Minister, he pointed out that his work had "raised the public health protection of this country from chaos to its present approach to perfection". At the very least, he asked an appointment "for a brief tenure" as deputy minister, after which he could serve as consulting sanitary adviser. ${ }^{54}$

A younger man, well qualified and with extensive experience in Europe during the war, was named to the post Montizambert craved. For Dr John Amyot, Montizambert quickly became a nuisance. He was put in charge of quarantine in the Division of Quarantine, Immigration and Marine. Amyot preferred to reorganize the whole division and to build a department which would not have to incorporate Montizambert and others, such as P.H. Bryce, who had run separate operations in different departments before being transferred into public health. The reorganization, however, could not "very well be put in operation so long as Dr. Montizambert is continued in his present state." Amyot hoped for Montizambert's resignation.

In February 1920, Montizambert was knocked down and injured by a streetcar. He returned to work in six weeks, but Amyot took the opportunity to set his retirement in motion. ${ }^{55}$ The details of his retirement brought one last clash over salary. Montizambert's salary was raised to $\$ 6000$ with the increase backdated one year. In return, he had to waive his right to one year's leave before retirement. As this leave was customarily granted to retiring public servants to improve their pensions, Montizambert was rightly upset. He wrote to Prime Minister Robert Borden to protest and to ask for an interview. Borden replied that "incessant imperative demands upon my time" made it impossible for him to attend to such administrative details. It was a far cry from the days of Sir John Macdonald when Montizambert had been able to arrange a number of personal interviews. When Montizambert's retirement, after fifty-four years in the public service, was announced in the House of Commons a member asked if this had been done on his own request. "No", J.A. Calder replied, "I can hardly say that. I think he was quite prepared to carry on." Montizambert lived an active life in retirement until his death late in $1929 .{ }^{56}$

Montizambert's long career covered a period of growing interest in public health and expanding scientific knowledge. Never an originator, Montizambert's great strength as a public health officer was in keeping abreast of these rapid developments and adapting the practice of his service to accommodate them. The structure of

\footnotetext{
5414 January 1919, FM to Francis H. Gisborne, PAC RG29, vol. 19, file 10-3-1, pt. 2; 27 May 1919 , FM to Sir Robert Borden, PAC RG32 C2, vol. 191. FM was given the Imperial Service Order in 1903 and made a CMG in 1916.

5511 April 1920, J.A. Amyot to N.W. Rowell, PAC RG32 C2, vol. 191.

5629 May 1920, FM to Sir Robert Borden; 31 May 1920, Borden to FM, PAC MG26 H1(1), vol. 165, 90015-17; PAC RG32 C2, vol. 191; HC Debates (1921) 3128, 3134; Ottawa Citizen, 4 November 1929, FM died 2 November 1929.
} 


\section{G. Bilson}

government in Canada limited Montizambert's activities largely to the quarantine service and his work there, on one of the continent's major immigration routes, brought him international recognition. As the administrator of the quarantine, he was sometimes at odds with provincial colleagues in public health who criticized the quarantine for failing to exclude disease from Canada. In his later years, especially after his appointment as Director General of Public Health, his understanding of the scope of public health work began to expand but he could never bring to it the range of experience, for example, that a medical officer of a large urban centre acquired. This fact, plus his advanced age and the desire to bring in someone from outside the federal service, lay behind the decision not to make him deputy minister of the Department of Public Health in 1919.

One cannot escape the feeling that Montizambert was not popular with his superiors. While he claimed to confine his lobbying to correspondence within the department, he did publish requests for changes at the stations in his annual reports. These occasionally served as ammunition for the opposition. Montizambert also expressed his opinion forcefully to opposition MPs from time to time. He was not, however, a publicist known to a large public like some of his public health colleagues. As one of the few full-time medical men in the federal service, Montizambert fought alone for the professional standing and financial reward he felt he deserved as recognition for his services in a specialized branch of medicine. His superiors did not accept his claims to professional independence, but insisted on their right to ultimate control over his actions. Only after his appointment as DGPH did Montizambert achieve an income which he felt truly reflected the value of his services to the country. Despite the rebuffs of his political superiors, however, Montizambert by the end of his career looked back with a satisfaction bordering on smugness at his achievements in public health. 